\title{
A Tér és Társadalom 2015-ben
}

\author{
Space and Society in 2015
}

\section{CZIRFUSZ MÁRTON, TAGAI GERGELY}

\begin{abstract}
CZIRFUSZ Márton: tudományos munkatárs, MTA Közgazdaság- és Regionális Tudományi Kutatóközpont, Regionális Kutatások Intézete, Budapest; czirfusz@rkk.hu TAGAI Gergely: tudományos munkatárs, MTA Közgazdaság- és Regionális Tudományi Kutatóközpont, Regionális Kutatások Intézete, Budapest; tagai@rkk.hu
\end{abstract}

\begin{abstract}
Márton CZIRFUSZ: research fellow, Institute for Regional Studies, Centre for Economic and Regional Studies, Hungarian Academy of Sciences, Budapest; czirfusz@rkk.hu Gergely TAGAI: research fellow, Institute for Regional Studies, Centre for Economic and Regional Studies, Hungarian Academy of Sciences, Budapest; tagai@rkk.hu
\end{abstract}

A Tér és Társadalom elmúlt évi szerzőiről és lektorairól a hagyományos összefoglalót idén is elkészítettük. A honlap mögött levő szerkesztőségi rendszer 2011-ben állt fel, így az elmúlt öt év tendenciáit együttesen vizsgáljuk a rendelkezésre álló adatok alapján.

\section{A folyóirat szerzői 2015-ben}

2015-ben is a korábbi évek megjelenéseihez hasonló nagyságrendű, szám szerint 55 tanulmány és egyéb rövidebb terjedelmü írás (könyvismertető, konferenciabeszámoló stb.) jelent meg a folyóiratban. A megjelentetett tanulmányokat ebben az évben 72 különböző szerző jegyezte, egyszerzős írásként, párban vagy nagyobb szerzői kollektíva tagjaként. Az elmúlt években állandósult az a tendencia, hogy folyóiratunk szerzői elsősorban az MTA kutatóhálózata intézeteinek szakembereiből (2015-ben 33 fö), illetve különböző hazai és külföldi felsőoktatási intézményeken oktató/kutató kollégák közül (2015-ben 35 fö) kerülnek ki. A tavalyi évben mindössze néhány tanulmányban vagy egyéb írásban működött közre olyan szerző, aki nem ezzel a háttérrel rendelkezett (pl. állami, kormányzati szféra, nyugdíjas kutató). 2015-ben a korábbi évekhez képest is magas volt az MTA KRTK Regionális Kutatások Intézetében dolgozó szerzőink száma, összesen 29 munkatársunk írását lehetett olvasni a

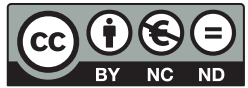


tavalyi lapszámokban. Ehhez a magas értékhez az is hozzájárult, hogy 2015-ös első számunk egy horizontális RKI-s kutatáshoz kapcsolódó, tematikailag összefüggő tanulmányokat mutatott be (vidékkutatás), Perger Éva, az RKI Alföldi Tudományos Osztályának vezetője vendégszerkesztésével. 2015-ben az MTA KRTK társintézményeiből két szerző írását lehetett olvasni a Tér és Társadalom lapjain, és szintén két, egyéb MTA kutatóintézeti háttérrel rendelkező szerző (Szociológiai Intézet, Politikatudományi Intézet) publikált folyóiratunkban.

A felsőoktatási intézményekben kutató 2015-ös szerzők közül többen nem hazai egyetemen vagy főiskolán végzik munkájukat. Tavaly több szerzőt is adott a Tér és Társadalom számára a Bécsi Egyetem, de franciaországi, angliai, németországi, oroszországi és romániai kutatóhelyekről is kaptunk tanulmányokat. Örömteli, hogy határon túli magyar szerzőink mellett külföldi szakembereket is sikerült megszólítanunk, akik önállóan vagy hazai szerzőtársakhoz csatlakozva publikáltak a folyóiratban. Ez a nemzetközi nyitás törekvésének apró sikerét is mutatja. A magyarországi szerzők területi megoszlásában a korábbi évektől eltérően 2015-ben kevésbé volt jellemző a budapesti kutatók túlsúlya. Bár relatíve a legtöbben tavaly is budapesti kutatóintézetekből és felsőoktatási intézményekből érkeztek szerzőink (20fö), arányuk az összes szerzőt tekintve a 30\%-ot sem éri el. A korábbi évekhez hasonlóan 2015-ben is pécsi kutatóhelyekhez (RKI Dunántúli Tudományos Osztály, Pécsi Tudományegyetem)

1. ábra: A Tér és Társadalom szerzőinek (munkahely szerinti) területi megoszlása, 2015 Spatial distribution of Space and Society's authors (according to workplace), 2015

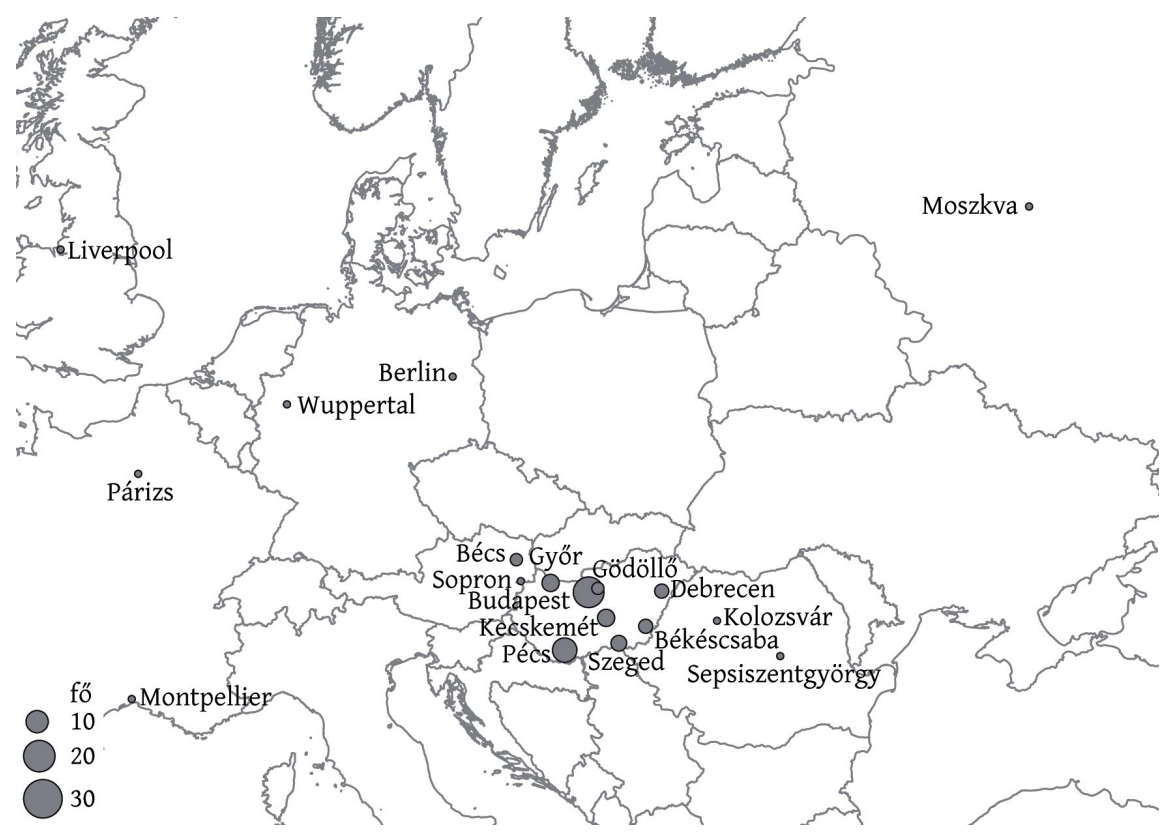


köthető szerzőktől érkeztek még jelentősebb számban tanulmányok, illetve beszámolók - tavaly tucatnyi pécsi kolléga írását tudtuk közölni a folyóirat hasábjain. A további vidéki felsőoktatási és kutatóközpontok közül Győr, Kecskemét (6-6 fö), Szeged (5 fö), Debrecen, Békéscsaba (4-4fö) adott nagyobb számban szerzőket a Tér és Társadalom számára, de emellett gödöllői és soproni szerzők írásai is megjelentek a folyóiratban (1.ábra).

Az elmúlt évek tendenciáihoz hasonlóan a Tér és Társadalom szerzőinek tudományterületi hovatartozása többnyire néhány társadalomtudományi szakterületre és kisebb mértékben további rokon- és társtudományokra korlátozódott. Akadémiai köztestületi, illetve intézményi hovatartozásuk alapján 2015-ben is regionalista szerzőink képezték a legnagyobb csoportot (27fö). Szerzőink másik nagy csoportját a társadalom-földrajzos kutatók képviselték 23 fővel. Emellett a szociológia és a közgazdaság-tudomány területéről is számos kutató publikált a folyóiratban. 2015-ben több szerzőnk tudományterületi hátterét jelentették az állam- és jogtudományok vagy a természetföldrajz, de egy-egy szerző képviselte folyóiratunkban a környezettudományt, a kulturális antropológiát, a nyelvtudományt, a politikatudományt és az urbanisztikát is. Ezzel a Tér és Társadalom szerzőinek szakterületi bázisa a korábbi évekhez képest némileg szélesedett, jelezve folyóiratunk nyitási törekvését más tudományágak felé.

A területi kutatásokkal foglalkozó szakmák és rokontudományok széles hazai merítését jelzi, hogy 2011 és 2015 között szerzőként majdnem 300 szakember publikált a Tér és Társadalomban (1. táblázat). Ez éves szinten 70-80 különböző szerzőt jelentett ebben az időszakban. A szerzők éves szinten stabil számából csak viszonylag kis hányadot tesznek ki rendszeres szerzőink (6fó), akik az elmúlt ötéves időszakban szinte minden évben megjelentettek valamilyen tanulmányt vagy egyéb rövidebb írást a folyóiratban. Viszonylag magasnak tekinthető ezzel szemben a visszatérő szerzők száma (59), akik 2011 és 2015 között két vagy három évben is publikáltak a folyóiratban. A TéT-ben megjelenő szerzők legnagyobb hányada azonban csak egyszer jelentkezett írásával a különböző lapszámokban az elmúlt öt év folyamán. Ez egyrészt örömteli abból a

1. táblázat: A Tér és Társadalom szerzői és lektorai 2011-2015 Authors and reviewers of Space and Society 2011-2015

\begin{tabular}{llrc}
\hline & & Szerzők & Lektorok \\
\hline Szerzők/lektorok száma & 2011 & 81 & 90 \\
& 2012 & 72 & 62 \\
& 2013 & 72 & 73 \\
& 2014 & 84 & 63 \\
& 2015 & 72 & 64 \\
\cline { 2 - 4 } & Összesen 2011-2015 & 289 & 188 \\
\hline Publikálás/lektorálás gyakorisága & Egy alkalommal & 224 & 103 \\
& Visszatérő (2-3 év) & 59 & 62 \\
& Rendszeres (4-5 év) & 6 & 23 \\
\hline
\end{tabular}


szempontból, hogy mindig újabb és újabb körökből sikerül szakembereket bevonni a Tér és Társadalom publikációs folyamatába, másrészt pedig reméljük, hogy a jövőben többüket sikerül újra megszólítanunk, hogy a folyóirat visszatérő, illetve rendszeres szerzőivé váljanak.

2015-ben a következő személyek írásai jelentek meg a folyóiratban:

$\begin{array}{lll}\text { A. Gergely András } & \text { Heintel, Martin } & \text { Ortiz, Willington } \\ \text { Balogh Gábor } & \text { Horeczki Réka } & \text { Patay Tünde } \\ \text { Barta Györgyi } & \text { Horváth Gyula } & \text { Perger Éva } \\ \text { Berki Márton } & \text { Horváth M. Tamás } & \text { Pete Márton } \\ \text { Bodor Ákos } & \text { Hoyk Edit } & \text { Pitó Klára } \\ \text { Borbély Sándor } & \text { Jankó Ferenc } & \text { Póla Péter } \\ \text { Brenner János } & \text { Káposzta József } & \text { Rácz Szilárd } \\ \text { Chevalier, Pascal } & \text { Kassai Zsuzsanna } & \text { Rakonczai János } \\ \text { Czakó Katalin } & \text { Király Gábor } & \text { Ritter Krisztián } \\ \text { Czirfusz Márton } & \text { Koós Bálint } & \text { Soltész Béla } \\ \text { Csák László } & \text { Kovács András Donát } & \text { Somogyvári Márta } \\ \text { Csatári Bálint } & \text { Kovács Áron } & \text { Szabó Tünde } \\ \text { Csomós György } & \text { Kovács Sándor Zsolt } & \text { Szakálné Kanó Izabella } \\ \text { Debre, Barbara } & \text { Kucséber László Zoltán } & \text { SzörényinéKukorelliIrén } \\ \text { Erdősi Ferenc } & \text { Lengyel Imre } & \text { Tagai Gergely } \\ \text { Fabók Márton } & \text { Lengyel Máté István } & \text { Timár Judit } \\ \text { Farkas Jenő Zsolt } & \text { Lennert József } & \text { Váradi Monika Mária } \\ \text { FehérKatalin(MTAKRTK) } & \text { Maurel, Marie-Claude } & \text { Varga Ágnes } \\ \text { Fehér Katalin (BGF) } & \text { Molnár Ernő } & \text { Varjú Viktor } \\ \text { Fertő Imre } & \text { Nagy A. Júlia } & \text { Vas Zsófia } \\ \text { Finta István } & \text { Nagy Erika } & \text { Vaszari Tamás } \\ \text { Fleischer Tamás } & \text { Nagy Gábor } & \text { Velkey Gábor } \\ \text { Grúber Károly } & \text { Németh Krisztina } & \text { Virág Tünde } \\ \text { Hamar Anna } & \text { Orbán Endre } & \text { Weixlbaumer, Norbert }\end{array}$

\section{A folyóirat lektorai 2015-ben}

A lektorok a folyóirat színvonalának fenntartásában fontos szerepet töltenek be: a legelső szerkesztőségi szürő után (amelyben a legalapvetőbb formai követelmények meglétét, illetve a folyóirat profiljához való illeszkedést vizsgáljuk) az ő kezükben van a tanulmányok szakmai színvonalának szigorú megítélése, a szerzők segítése a kéziratok javításában.

2015-ben a 65 lektor kiválasztásakor a korábbi évekhez hasonlóan az MTA KRTK Regionális Kutatások Intézetének kutatóira építettünk (itt dolgozik a lektorok 42\%-a), rajtuk kívül három kollégát kértünk fel az MTA KRTK másik két intézetéből a tanulmányok bírálatára. A lektorok másik nagy köre az egyeteme- 
ken és főiskolákon dolgozóké: 2015-ben 22 kollégánk elsődleges munkahelye a felsőoktatás. A szerzői összeállításból látható volt, hogy 2015-ben a korábbinál több rokon tudomány térrel foglalkozó társadalomtudományi tanulmányai jelentek meg a lapban, ezzel párhuzamos jelenség, hogy más MTA kutatóközpontok (Társadalomtudományi, Csillagászati és Földtudományi) dolgozói is lektoráltak cikkeket a Tér és Társadalom számára. Az államigazgatásban, nem MTA-kutatóhelyeken, a magánszférában dolgozó, illetve nyugdíjas szakembereket tavaly is felkértünk a szerkesztőségbe érkező cikkek bírálatára. 2015-ben is törekedtünk arra, hogy a pályájuk különböző szakaszán levő szakembereket szólítsunk meg: jelentős számban készítettek lektori véleményeket 40 év alatti kutatók a tapasztalt kollégák mellett; a lektorálásra való felkérést a tudományos utánpótlás-nevelés egyik eszközének is tekintjük. A 2015/1. tematikus lapszám valamennyi tanulmányát ugyanazon két lektor bírálta (ahogy ez a vendégszerkesztett lapszámoknál a korábbi években bevált gyakorlattá vált), ezzel biztosítottuk az írások nagyobb tematikus és színvonalbeli koherenciáját.

A lektorok területi megoszlásában a budapesti túlsúly az elmúlt 5 évet vizsgálva 2015-ben a legalacsonyabb volt, de még így is 44\%-ot ért el. 2014-hez hasonlóan (azonos százalékértékkel) a második legnagyobb lektori bázisunk Pécs: itt dolgozik a lektorok 16\%-a. A városok következő hierarchiaszintjén Kecskemét, Győr és Szeged található (4-6 fővel), 1-2 fő lektorált Békéscsabáról, Debrecenből, Gödöllőről, Miskolcról, Sopronból, Székesfehérvárról; a határon túli kollégák közül egy pozsonyit és egy újvidékit kértünk fel bírálatra (2. ábra).

A 2011 és 2015 közötti adatokat elemezve (1. táblázat) látszik, hogy a szerzőkhöz képest (elsősorban a társszerzős tanulmányok száma, illetve a nem lektorált rovatban megjelent írások miatt) alacsonyabb a lektorok száma, 188 fó került kapcsolatba ilyen módon a folyóirattal. A lektorok nagyjából nyolcadrésze rendszeres lektorunk, azaz az elmúlt 5 évben 4-5 évben is felkértük őket egy-egy cikk bírálatára. A lektorok harmada sorolható a visszatérő csoportba, azaz 2-3 évben készített a tanulmányokról szakmai véleményt. 103 fó azok száma, akiket az elmúlt öt évben egyszer kértünk fel. A szerzői megoszlással összevetve tehát a lektorokat kevésbé váltogatta a szerkesztőség. Például a 2011-es és 2015-ös év lektorai között 34 fö az átfedés (ez a 2015-ös bírálók több mint fele), viszont 2015ben 11 olyan lektorral dolgoztunk együtt, akikkel az elmúlt öt évben még nem (közülük négyen RKI-s kollégáink). A lektorok körének változása vagy állandósága ugyanakkor nem önérték: ezt nagyban befolyásolja a szerkesztőségbe érkező kéziratok tematikai, elméleti, módszertani spektruma és az összeférhetetlenségi szempont (közvetlen kollégákat, korábbi vagy jelenlegi témavezetőket nem szoktunk felkérni a tanulmányok bírálatára), illetve nem kétséges, hogy a korábban magas színvonalú bírálatokat készítő kutatótársainkat szívesen kérjük fel ismét lektorálásra, ha profiljukhoz illeszkedő kéziratot kapunk. Továbbra is biztatjuk olvasóinkat, hogy a Tér és Társadalom honlapján lektorként is regisztráljanak, és a felhasználói fiókjukban adják meg kulcsszavakkal kutatási területeiket, ezzel segítve a szerkesztőség munkáját a lektorok körének jövőbeli bővítésében. 
2. ábra: A Tér és Társadalom lektorainak (munkahely szerinti) területi megoszlása, 2015 Spatial distribution of Space and Society's reviewers (according to workplace), 2015

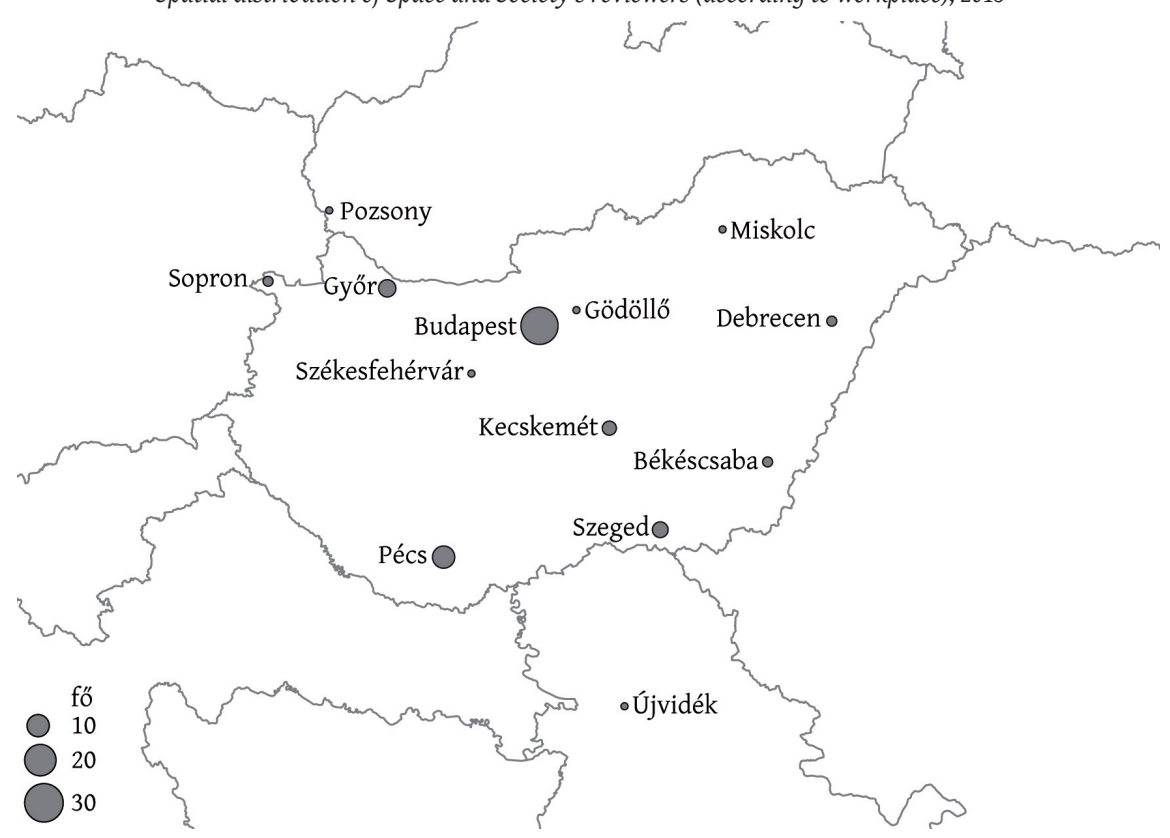

A Tér és Társadalom angol nyelvü absztraktjainak alapos, körültekintő nyelvi javítását 2015-ben is Thomas Richers végezte. A lektorok listájának közlésével ezúton is köszönjük mindannyiuknak a tavalyi munkát, amelyet a folyóirat számára végeztek.

2015. január és december között lektoraink voltak:

$\begin{array}{lll}\text { A. Gergely András } & \text { Fabula Szabolcs } & \text { Jeney László } \\ \text { Barta Györgyi } & \text { Faragó László } & \text { Kiss Judit } \\ \text { Beluszky Pál } & \text { Farkas Jenő Zsolt } & \text { Koós Bálint } \\ \text { Berki Márton } & \text { Fleischer Tamás } & \text { Kovács András Donát } \\ \text { Bernek Ágnes } & \text { G. Fekete Éva } & \text { Kozma Gábor } \\ \text { Bodor Ákos } & \text { Gál Zoltán } & \text { Lengyel Imre } \\ \text { Boros Lajos } & \text { Hajdú Zoltán } & \text { Lukovics Miklós } \\ \text { Czirfusz Márton } & \text { Hakszer Richárd } & \text { Lux Gábor } \\ \text { Csanádi Gábor } & \text { Hamar Anna } & \text { Michalkó Gábor } \\ \text { Csatári Bálint } & \text { Hardi Tamás } & \text { Molnár Ernő } \\ \text { Csizmadia Zoltán } & \text { Horváth Gyula } & \text { Nagy Gábor } \\ \text { Dusek Tamás } & \text { Illés Sándor } & \text { Nagy Imre } \\ \text { Erdősi Ferenc } & \text { Jakobi Ákos } & \text { Pál Viktor } \\ \text { Fábián Attila } & \text { Jelinek Csaba } & \text { Pálné Kovács Ilona }\end{array}$


Perger Éva

Rácz Katalin

Rátz Tamara

Rechnitzer János

Rédei Mária

Reisinger Adrienn

Ságvári Bence

Sikos T. Tamás
Szalavetz Andrea

Szalkai Gábor

Szirmai Viktória

SzörényinéKukorelliIrén

Tagai Gergely

Tosics Iván

Tóth Balázs István

Törőcsik Mária
Uzzoli Annamária

Váradi Monika Mária

Varjú Viktor

Velkey Gábor

Vida Zsófia

Virág Tünde 